\title{
RESEARCH OF THE RHYTHMICAL ABILITIES OF RHYTHMIC GYMNASTS
}

\author{
Giurka Gantcheva, Emil Videv, Bisser Grigorov \\ National Sports Academy „Vassil Levski““
}

\begin{abstract}
Rhythmical abilities, being part of the coordination abilities of athletes, are an important factor for the successful realization in the complex-coordination kinds of sports. The initial learning of the exercises requires the strict following of a rhythm, set with music, to distinguish the different phases of motor activities and their duration. The rhythm of motor activities is subjected to the inner rhythm of the performer, to the different rhythm of the movements with the apparatuses, and to the rhythmical structure of the music accompaniment. The rhythmical execution and the harmonious connection between movements and music is one of the major characteristics of gymnastics events. The aim of the research is to study the rhythmical abilities of athletes, practicing kinds of sports whose motor activity requires the use of musical accompaniment and those which do not require such. The research was done among 72 individuals. Methods: For coordination in rhythm we used four tests: Frontalkickingwithlegsandarmsonthewall - (Fkla), Jumpsinfoursquares - (J4sq), Crossover jumps in four squares - (Cj4sq), Kicking with legs and arms - (Kla).

The results from the tests - Jumps in four squares $u$ Crossover jumps in four squares - correlate with each other significantly with the gymnasts (.710**) and moderately with the athletes practicing other kinds of sports (.358**). The results from the agility tests correlate significantly with the gymnasts $\left(.723^{*}\right)$, and moderately with the athletes from the other sports $\left(.654^{* *}\right)$. The mean values $(\overline{\mathrm{x}}=10.20$, $\overline{\mathrm{x}}=4.41)$ and $(\overline{\mathrm{x}}=10.6, \overline{\mathrm{x}}=8.24)$ of the tests, performed with arms and legs are better with the gymnasts. The results from the research showed the necessity of adapting the applied tests so that they could be implemented in research with different age groups.
\end{abstract}

Key words: rhythmical abilities, gymnastics, other sports, music accompaniment

\section{INTRODUCTION}

The rhythm of human activities can be generally defined as a way of synchronization or unification of the rhythms between the movements of different body parts, between moving object and person, two people, and a person and melody (Schaal, et al, 2004). Being an inborn sense, rhtyhm is present in almost all human daily activities, and in the very human organism - heart rate, breathing, etc. (Zachopoulou, Tsapakidou and Derri, 2004). All body systems (respiratory, cardiovascular, locomotory) work in a certain rhythm. In this complex sense, rhythm has a particular place in human organism both for maintaining its homeostasis and for performing its movements (Jeffcock, 2006).
The ability to feel and reproduce rhythm is in the base of a number of sports disciplines, called "artistic" because of the synchronization of human movements with music - rhythmic gymnastics, synchronized swimming, figure skating, sports dances (Karpenko, 2003). It is considered one of the most important complex qualities and the nature of these disciplines requires its continuous perfection (Rosato, Fazio, 2006).

The rhythmical ability, defined as a component of coordination abilities, has its manifestation in gymnastics disciplines - rhythmic, aesthetic, artistic gymnastics, aerobics, sports acrobatics, where routines are performed with music accompaniment (Hadjiev, et al., 2011). 


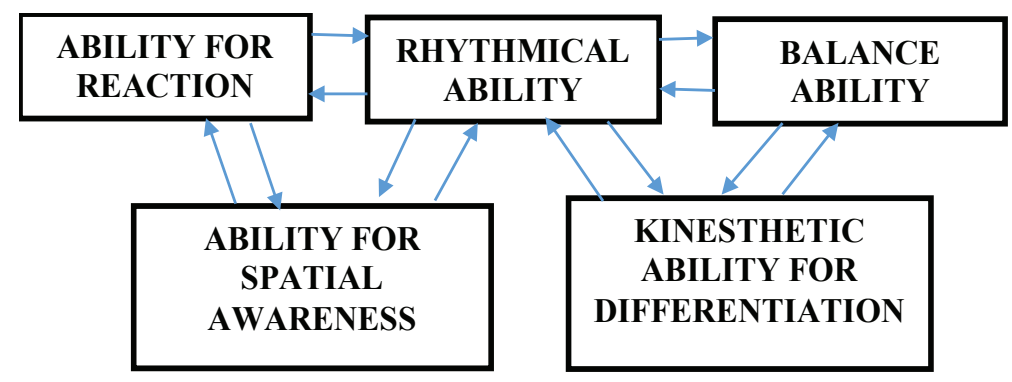

Figure 1. Components of coordination abilitiesin gymnastics (according to Hadjiev, $N$., $K$.

Andonov, D. Dobrev, V. Petrov)

Human movements can adapt their rhythm to an outer rhythm (Hafe, 2016). In gymnastics this is expressed through the adaptation to the relation music-movement and the connection of the music phrases, accents, rhythm and specific dynamics (Rosato, 2006). Music is the only means which, during motor activity, could set the exact rhythm of performance and measure precisely the continuation of the different phases of the movements (Viner-Usmanova, 2015). It is also an accurate reference point for restoration of the execution precision when a mistake has been made (Marcez, DiSanto, 2000).

Music rhythm influences on a great extent the process of mutual actions in group gymnastics (Gantcheva, 2017) but is also an important element in the contents of the curative kinds of gymnastics aimed at developing biological abilities of human body, adequate breathing rhythm which facilitates the adaptation of organisms to the environment (Macovei, 2006). Rhythmical abilities, being a phenomenon in the field of physical culture, have provoked interest in lots of researchers in the field of gymnastics in their attempt to solve some curative, aesthetic, general development and rehabilitation tasks (Terehina, 1991, Sosina, 2009).

The evaluation of rhythmical abilities, based on subjective criteria, makes it difficult to establish their qualitative and quantitative parameters. In this connection, Damjanovska,
Gontarev, Radisavljevic, (2013) created three new tests for evaluation of coordination in rhythm, which showed there were good measuring characteristics which could be used in practice.

In the artistic disciplines, where the relation music-movements is particularly important, researchers use tests including movements close in structure to basic movements in the certain discipline (Dimitrova, 2015). Setting a rhythm and tempo of execution with the use of a metronome or the modified option - the use of music accompaniment with preliminarily set moderate tempo (122 or 128 beats per min) is a successful way to unite the two components of the discipline-movement and music (Tarnichkova, 2016).

Aim: The aim of the research is to study the rhythmical abilities of athletes, practicing kinds of sports whose motor activity requires the use of musical accompaniment and those which do not require such.

\section{METHODOLOGY}

\section{Paticipants}

The research was done among 72 female athletes, practicing different kinds of sports: 35 gymnasts (rhythmic and aesthetic) with average age 20.91 years and 37 individuals, practicing other kinds of sports (athletics, tennis, volleyball, and wrestling) with average age 21.22 years. 


\section{Methods}

In order to fulfill the aim of the research we used tests recommended by (Damjanovska, Gontarev, Radisavljevic (2013) and by (Damjanovska, et al., 2015):

Four tests for assessment of coordination in rhythm were used:

Frontal kicking with legs and arms on the wall - (Fkla)

On the floor in length of $20 \mathrm{~cm}$ from the wall, is marked a line, behind which stands the examiner in upright position, turned with its face to the wall. Also, in $20 \mathrm{~cm}$ height is drawn a line. Hands of subjects are raisedat a right angle in the height of the shoulders. With in 20 seconds, the examiner should do the following actions: with his right foot hits the wall over the line, lowers his right foot on the floor, then takes a shot with his left foot, lowers the legd own to the floor. Then follows alternately hits with hands to the wall as follows: right hand, than with the lefth and and again with the right one. That is one cycle of movement. The next cycle of movement starts with a hit of his left foot to the wall, and then with the right foot continuing with alternately hitting the left, right, left hand to the wall. Cycles of movements is performed by the end of 20 seconds. The test is repeated three times, the number of successfully performed cycles is recorded. Practicing is not allowed.

\section{Jumps in four squares - (J4sq)}

In the floor are painted four squares of the same dimension 40x40 cm, spaced from each other in $5 \mathrm{~cm}$. The examiner stands in upright position, with free slumped hands beside the body, in the right lower square. The movement starts with a jump of the right foot in the right upper square, jump in gwith the left foot in the left upper square, starting with the right foot in the lower left square and taking three steps (right, left, right foot), after the performed three steps, with his left foot jumps in the left upper square, with the right foot jumps in the top right square, and starting with the left foot in the lower right square takes three steps (left, right, left foot). This makes one cycle of movements. The test is repeated three times, the number of successfully performed cycles in 20 seconds is recorded.

Practicing is not allowed.

Crossover jumps in fours quares - (Cj4sq)

Is the same as the previous test, but here the movement starts with left foot jump in the left upper square, and with his right foot in the right upper square, with the left leg jump in the lower left square is performed three steps (left, right, left foot). Then the movement starts with the right foot jump in the top rights quare, then with left foot jump in the left upper square, and starting with the right foot in the lower right square is performed three steps (right, left, right foot). This makes one cycle of movement. The test is repeated three times, the number of successfully performed cycles in 20 seconds is recorded. Practicing is not allowed.

\section{Kicking with legs and arms - (Kla)}

This test is performed in the corner of a room. On the left and right side of the floor, in height and distance from the floor, are marked lines with a length of $20 \mathrm{~cm}$. Respondent in upright position, with arms raised to the level of the shoulders, stands on the marked place. With the right side of the body the hits are performed to the right side wall, while with left side of the body to the left side of the wall. But the movements are performed as follows: the respondent with the left foot hits the left wall above the line and lowers the leg on the 
floor, with his right hand hits the right wall at the height of the chests, separates the arm from the wall, with his left hand, at the height of the chests, hits two consecutive times in the left wall, separates the left hand from the wall, with the right foot strikes the right wall and lowers the leg on the floor. This makes one cycle of movement. Respondent, starting with hitting with his left foot into the left wall opens the next cycle of movement. The test is repeated three times, the number of successfully performed cyclesin 20 seconds is recorded. Practicing is not allowed.

Each test was executed three times, consecuitively, with short breaks between the different trials, but only the best result was taken into consideration.

\section{Math-statistical methods:}

Correlation analysis and variation analysis of the results from the research aimed at establishing the statistically significant relations between the variables of coordination in rhythm.

All statistical analyses were performed with the use of SPSS 19.

\section{RESULTS}

The results from the variation analysis are presented in tables 1 and 2 . The average number of complete cycles for each of the tests ranges from 7.09 and 10.6 with the gymnasts and 4.41 and 8.24 with the athletes practicing other kinds of sport. With all the applied tests the variation of the values is relatively great because, with both research groups the coefficient of variation is over $10 \%$. There is a normal distribution of the values. This is justified by the coefficients of asymmetry and excess. The values of the range $(\mathrm{R})$ are approximately the same with the exception of test Frontalkicking with legs and arms on the wall, with $\mathrm{R}=15$ for the gymnasts' group and $\mathrm{R}=11$ for the other atheletes' group. The mean values of the results from the tests are higher with the gymnasts. The obtained results from the tests performed with legs and arms - Frontal kicking with legs and arms on the wall ( $\mathrm{x}=10.20, S=3,16 ; \mathrm{x}=4.41, S=2,05$ ) and Kicking with legs and arms ( $\mathrm{x}=10.6$, $S=3.03 ; \overline{\mathrm{x}}=8.24, S=3,35)$ are especially interesting. There is a moderate correlation dependence among the results from three tests for coordination in rhythm with the gymnasts $(.473 *, .482 * *, .443 * *)$. The great significance of the tests, performed only with legs $(.710 * *)$ is the highest result in the present study (table $3)$. With the athletes practicing other kinds of sports we found weak dependence $(0,216)$ between the results form the tests performed with arms and legs. However, there is a significant dependence between the tests performed with arms and legs and only with legs $(.582 * *)$ (table 4). Rhythmicity of movements in other sports disciplines, even with lack of music accompaniment, is subjected to inner rhythm close to the natural rhythm of the body.

Table 1. Variation analysis of the results from the research among women-gymnastics

\begin{tabular}{ccccccccccc} 
& INDICATOR & $\mathbf{n}$ & $\mathbf{X m i n}$ & $\mathbf{X m a x}$ & $\mathbf{R}$ & $\mathbf{x}$ & $\mathbf{S}$ & $\mathbf{V}$ & $\mathbf{A s}$ & $\mathbf{E x}$ \\
\hline \multirow{2}{*}{1} & $\begin{array}{c}\text { Frontal kicking with legs and } \\
\text { arms on the wall }\end{array}$ & 35 & 5 & 20 & 15 & 10,20 & 3,16 & 30,98 & 1,027 & 1,698 \\
\hline 2 & Jumps in four squares & 35 & 3 & 11 & 8 & 7,23 & 1,90 & 26,22 & $-0,294$ & 0,174 \\
\hline 3 & $\begin{array}{c}\text { Crossover jumps in four } \\
\text { squares }\end{array}$ & 35 & 1 & 11 & 10 & 7,09 & 2,09 & 29,51 & $-0,509$ & 0,702 \\
\hline 4 & Kicking with legs and arms & 35 & 5 & 16 & 11 & 10,60 & 3,03 & 28,59 & $-0,057$ & $-0,622$ \\
\hline 5 & Height & 35 & 158 & 180 & 22 & 167,94 & 4,70 & 2,80 & 0,201 & 0,461 \\
\hline 6 & Weight & 35 & 45 & 63 & 18 & 54,66 & 3,96 & 7,24 & $-0,144$ & 0,305 \\
\hline
\end{tabular}


Table 2. Variation analysis of the results from the research among women-other sports

\begin{tabular}{ccccccccccc} 
& INDICATOR & $\mathbf{n}$ & $\mathbf{X m i n}$ & $\mathbf{X m a x}$ & $\mathbf{R}$ & $\mathbf{x}$ & $\mathbf{S}$ & $\mathbf{V}$ & $\mathbf{A s}$ & $\mathbf{E x}$ \\
\hline 1 & $\begin{array}{c}\text { Frontal kicking with legs } \\
\text { and arms on the wall }\end{array}$ & 37 & 2 & 13 & 11 & 4,41 & 2,05 & 46,42 & 2,350 & 7,910 \\
\hline 2 & Jumps in four squares & 37 & 4 & 11 & 7 & 6,89 & 1,70 & 24,62 & 0,431 & 0,142 \\
\hline 3 & $\begin{array}{c}\text { Crossover jumps in four } \\
\text { squares }\end{array}$ & 37 & 0 & 11 & 11 & 6,43 & 2,54 & 39,56 & $-0,377$ & 0,487 \\
\hline 4 & Kicking with legs and arms & 37 & 1 & 14 & 13 & 8,24 & 3,35 & 40,59 & $-0,360$ & $-0,146$ \\
\hline 5 & Height & 37 & 154 & 185 & 31 & 167,73 & 7,02 & 4,18 & 0,559 & 0,064 \\
\hline 6 & Weight & 37 & 45 & 75 & 30 & 57,59 & 7,59 & 13,17 & 0,610 & $-0,146$ \\
\hline
\end{tabular}

Table 3. Correlation matrix of the investigated parameters-Female gymnasts

Female gymnasts

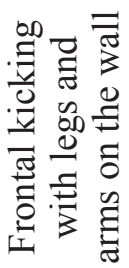

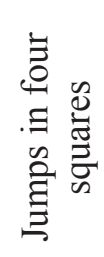

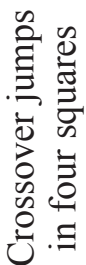

\begin{tabular}{ccccc}
\hline Frontal kicking with legs and arms on the wall & 1 & & & \\
\hline Jumps in four squares & 0,230 & 1 & & \\
\hline Crossover jumps in four squares & 0,125 & $\mathbf{, 7 1 0 * *}$ & 1 & \\
\hline Kicking with legs and arms & $\mathbf{4 7 3}^{*}$ & $\mathbf{4 8 2}^{* *}$ & $\mathbf{4 4 3}^{* *}$ & 1 \\
\hline *Significance at 0,05 level, **Significance at 0,01 level & & &
\end{tabular}

Table 4. Correlation matrix of the investigated parameters - Female athletes - other sports.

\begin{tabular}{|c|c|c|c|c|}
\hline Female athletes - other sports & 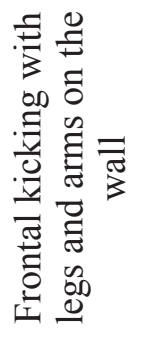 & 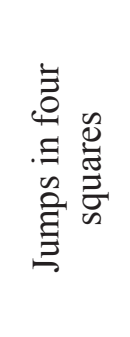 & 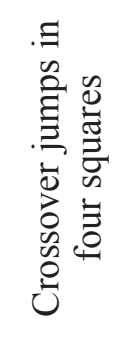 & 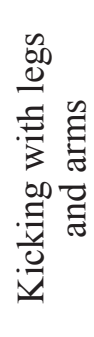 \\
\hline Frontal kicking with legs and arms on the wall & 1 & & & \\
\hline Jumps in four squares & $-0,128$ & 1 & & \\
\hline Cross jumps in four squares &, $582 * *$ & ,358** & 1 & \\
\hline Kicking with legs and arms & 0,216 & ,476* &, $518 * *$ & 1 \\
\hline
\end{tabular}

*Significance at 0,05 level, **Significance at 0,01 level 


\section{DISCUSSION}

The rhythmical abilities of the gymnasts are related to the nature of the discipline and to its requirements for simultaneous play with arms and legs, to the same, different or often changing rhythm. The skill to perform slow and graceful body movements (waves, dancing steps, turns) while following the melody of the music accompaniment, and performing quick and dynamic movements with the apparatus (snakes and spirals with ribbon, assimetrical movements with clubs, rotation with rope, consecutive rolls with a ball, hoop throws with simultaneous spins) according to the accents of the music are the base for the results obtained in the abovementioned tests.

The results from the tests, performed with legs and supportive free movement of the arms are a manifestation of the so-called ability to follow rhythm - when there is an outer rhythm of music accompaniment to express the rhythm through motor action (Mienel, Schnabell, 1987). Most often, these are different kinds of gymnastics or dance steps, depending on the character of the abovementioned music accompaniment, where the main movement is performed with legs.

The actions in rhythmic gymnastics, and in the other kinds of gymnastics, are preliminarily set, familiar and relatively constant as a model for motor activity. The perfection of the movements is subjected to reaching uniformity between the rhythm of the body and the one of the movements with the apparatuses through the rhythm of the music accompaniment. Musical means of expression (tempo, rhythm, dynamics, and melody) are basic measurement unit for perceiving the rhythm and execution of gymnastics movements, but also a reference point for evaluation of rhythmical abilities in gymnastics for exact and precise execution.

The rhythmical abilities with athletes practicing other kinds of sports are perfected in different conditions. The constantly changing environment in team sports and the lack of music accompaniment with a strictly set function, places the two groups in a totally different situation. The movements, performed only with feet, regardless of their thyrhmical structure, are close to the natural human movements and are influenced by the individual abilities to a great extent.

The abilities to feel and recreate the peculiarities of the sounds through movements are one of the basic qualities in gymnastics (Rosato, 2006). The execution of complex rhyhmical structures depends to a great extent both on the level of preparation and on the complexity of the used music forms, appropriate for the particular competitive category (Borissenko, 2000) and consequently, some amendments to the tests for rhythmical abilities are needed regarding the different age groups and levels of preparation.

\section{CONCLUSION}

Rhythmical abilities are one of the main factors for the successful realization in gymnastics due to the specifics of this motor activity, according to the rules of its evaluation and perception on behalf of the spectators. The development and perfection of rhythmical abilities in modern rhythmic gymnastics in relation to musical accompaniment should be subjected to the requirements of contemporary sport while preserving the traditions and richness of the music culture. The established correlation dependences show that the researched individuals did not find much difficulty in performing the applied tests, but the tests should be brought up to date and performed with different music accompaniment. Thus, a wider range of rhythmical abilities could be checked.

\section{REFERENCES}

Borissenko, S.I., (2000). Povishenie ispolnitelscogo masterstva gimnastok na osnove sovershenstvovania horeograficheskoi podgotovki, Avtoreferat disertacia kand.ped. nauk. 
- SPb, pp.21 // Борисенко, С.И. (2000). Повишение исполнительского мастерства гимнасток на основе совершенствования хореографической подготовки. Автореферат дисертация канд.пед.наук. СПб. с. 21.

Damjanovska, M., Gontarev, S., Rhedzepi, A., Gantcheva, G. (2015). Comparing reliability and validity of some tests with classic and image model of assessement rhythmic ability. Sborník př́spěvků z mezinárodní vědecké conference. Evropské Pedagogické Fórum, 23-27.11. Vol. V. ISBN 978-80-87952-11-5 Hardek Králové, Česká Republika.

Damjanovska, M., S. Gontarev, L. Radisavljevic (2013). Determination of measurement characteristics for rhythmic skill assessment's. Conference proceedings, Effects of Physical Activiti Application to Anthropological Status with Children, Youth and Adults. Univezrzitet u Beogradu, Fakultetsporta I fizickog vaspitanja, 11-12 decembar, Beograd.

Dimitrova, B. (2015). Coordination abilities and selection in gymnastics. Activities in Physical Education and Sport. Vol. 5, No.2, pp. 214-243.

Gantcheva, G. (2017). Survey of the difficulty-composition relation with the ensembles in Rhythmic gymnastics, Research in kinesiology, International Journal of Kinesiology and Other Related Sciences, Federation of the Sports Pedagogues of the Republic of Macedonia, Skopje, 7-9.

Hadjiev, H., et al., (2011). Gymnastika fizicheska podgotovka. NSA PRES, Sofia, pp.101-115. // Хаджиев, Н. и кол. (2011). Гимнастика - физическа подготовка, НСА ПРЕС, София. pp. 101-115.

Hafe, R., A. (2016). Impact of coordination abilities program on accuracy and speed in rhythmic gymnastics. Science, Movement and Health, Vol. XVI, ISSUE 16 (2), 141-146.

Jeffcock, D. (Director). (2006). How music works with Howard Goodall - 02 Rhythm [Motion Picture].
Macovei, S. (2006). Balance - technical requirement and specific motor quality - from the oryto practice. International Meetingon Rhythmic Gymnastics: identity and sports issues. Torino. Italy.pp. 46-55.

Marcez, S., Di Santo, M. (2000). El papel de la retroinformacion en el aprendizaje de gestosmotores en la gimnasiaritmica. Licenciatura. Instituto del profesorado en Educacion Fisica de Cordoba. Rio Cuatro.

Mienel, Y., Schnabell, G. (1987). Teoría Del Movimiento, Editorial Stadium. Buenos Aires.

Rosato, M-R. (2006). Relazione tra ritmo movimenti ed il ritmo-musicale ne gliesercizi de GR. International Meeting on Rhythmic Gymnastics: identity and sports issues. Torino, Italy, pp. 138-143.

Rosato, M-R., Fazio, I. (2006). La valutazione del „senso ritmico“ nella GR. International Meeting on Rhythmic Gymnastics: identity and sports issues. Torino, Italy, pp. 80-92

Schaal, D., Sternad, R., Osu, R., \& Kawato, M. (2004). Rhythmic arm movement is not discrete. Nature Neuroscience, pp. 1136-1143.

Sosina, V. Y., (2009). Horeografia v gimnastike, Uchebnoe posobie dliastudentov, Moskva. Olimpiiska literatura. pp. 134-135 // Сосина, В.Ю. (2009). Хореография в гимнастике, Учебное пособие для студентов. Москва. Олимпийска литература. pp. 134-135.

Tarnichkova, M., (2016), Testovi control i otzenka na fizicheskata deesposobnost na sastezatelite $\mathrm{v}$ sportnata aerobika. Uchebno pomagalo. Sofia. NSA PRES // Търничкова, М. (2016). Тестови контрол и оценка на физическата дееспособност на състезателите в спортната аеробика. Учебно помагало. София. НСА ПРЕС.

Terehina, R. N., (1991). Metodika obuchenia tantzevalnim uprajneniam. Metod. rekomendacia /RN Teherina, NA Belova - SPb.: GDIOFK im P.F. Lesgafta, pp.37 // Терехина, Р.Н. (1991). Методика обучения 
танцевальным упражнениям. Метод. performance. Technological Educational Inрекомендация. / Р.Н. Терехина, Н.А. Белова. stitution of Tessaloniki, Department of Early - СПб.: ГДОИФК им. П.Ф. Лесгафта, с. 37. Childhood Care and Education, Early Child-

Viner-Usmanova, I. (2015). Teoria I meto- hood Research Quarterly 19, pp. 631-642.

dika hudojestvennoi gimnastike - artistich- Karpenko, L. A. (2003). Hudojestvennost I eio puti formirovania. Moskva. Izda- naia gimnastika, Uchebnik, Moskva, VFGH, telstvo "SPORT" //Винер-Усманова, И.А. SPGAFK “P.F.Lesgaft". // Карпенко, Л.А. (2015). Теория и методика художественной (2003). Художественная гимнастика, гимнастики - артистичност и её пути Учебник. Москва. ВФХГ, СПГАФК „П.Ф. формирования Москва. Издательство Лесгафт“.

„SPORT“.

Zachopolou, E., Tcapakidou, A., Derri, V. (2004). Effectsof a development all yappropriate music and movement program on motor

\section{Corresponding author:}

\section{Giurka Gantcheva}

Gymnastics Department

National Sports Academy „Vassil Levski“ Studentski grad, 21, Acad. Stefan Mladenov str. Sofia 1700, Bulgaria

E-mail: giurka@abv.bg 